\title{
ANALISIS TRANSPARANSI DAN AKUNTABILITAS OTONOMI DESA DALAM PENGELOLAAN DAN PERTANGGUNGJAWABAN ALOKASI DANA DESA DI DESA KAUNERAN SATU KECAMATAN SONDER KABUPATEN MINAHASA
}

\author{
Fernando Victory Tambuwun $^{1}$, Harijanto Sabijono ${ }^{2}$, Stanly W. Alexander ${ }^{3}$ \\ 1,2,3 Jurusan Akuntansi, Fakultas Ekonomi dan Bisnis, Universitas Sam Ratulangi, Jl.Kampus Bahu, Manado, \\ 95115, Indonesia \\ E-mail : Victorytambuwun.7@gmail.com
}

\begin{abstract}
The allocation of village funds is funds allocated by the district/municipality governments for villages sourced from the state budget and revenues or central and regional fiscal balances funds, used to finance the implementation of governance, development implementation, community development and community empowerment. The grant of village funds is done in several stages budgeting, allocation, distribution, use, reporting, and monitoring or evaluation of village funds. The objectives of this research is to find out the mechanism of channeling the allocation of village funds in the kauneran village of one of the subdistricts of sonder of minahasa district and to know the constraints faced in the tranparency and accountibility of the management of the village fund allocation in th kauneran village of one district of minahasa regency. The results of this study indicate that transparency and accountibility of gradual allocation of village funds from budgeting, allocation, use, reporting, and monitoring or evaluation work well.
\end{abstract}

Keywords : Allocation of village funds, Transparency, Accountibility

\section{PENDAHULUAN}

Alokasi Dana Desa (ADD) adalah Suatu dana bantuan dari pemerintah pusat yang disalurkan ke setiap kabupaten/kota untuk keperluan setiap desa, yang bersumber dari Anggaran pendapatan dan Belanja negara bagian keuangan perimbangan dana pusat dan daerah yang diperoleh setiap daerah kabupaten. Bertujuan untuk menjalankan dan memajukan pembangunan desa merupakan suatu bantuan dana langsung dari pemerintah pusat yang langsung dialokasikan kepada pemerintah desa digunakan untuk meningkatkan sarana pelayanan masyarakat dan administrasi pengelolanya dilakukan dan dipertanggungjawabkan pengguna dan pemakai dana tersebut, maka pemerintah dan aparatur desa harus memahami bagaimana pengelolaan keuangan desa.

Transparansi (Transparancy) adalah suatu keterbukaan untuk menyediakan informasi yang material dan relevan atau sebenarnya dengan cara yang mudah diakses dan dipahami bagi orang yang berkepentingan. Sedangkan menurut United Nation Development Program (UNDP) dalam mardiasmo (2013:19) menyatakan bahwa keterbukaan didirikan dalam kebebasan mendapatkan informasi. Suatu Informasi yang diperoleh sesuai dalam kepentingan masyarakat secara langsung dapat diperoleh kepada semua yang membutuhkan. Akuntabilitas (Accountibility) ialah kewajiban kepada tanggung jawab seorang pemegang amanah untuk mengelola, menyajikan, melaporkan serta menyampaikan segala aktivitas yang dilaksanakan kepada pemberi amanah. Mardiasmo (2014:20) menyatakan bahwa akuntabilitas dan transparansi merupakan komponen utama dari good corporate governance. Transparansi dan akuntabilitas merupakan suatu hal yang sangat penting bagi pengelolaan keuangan disetiap organisasi, baik organisasi pemerintah maupun non pemerintah. Pelaksanaan akuntabilitas dengan menjalankan prinsip-prinsip good governance sangat penting disetiap organisasi yang meliputi transparansi dan rasa keadilan, hal ini bertujuan 
agar organisasi tersebut dipercaya dapat oleh setiap stakeholder, oleh karena itu setiap organisasi di pemerintah diharuskan melaksanakan prinsip akuntabilitas tersebut.

Sejalan lewat berlangsungnya perkembangan otonomi daerah/desa yang memfokuskan diri pada mengupayakan pemberdayaan masyarakat desa, jadi peranan pemerintah daerah/desa tentu sangat penting menjadi suatu lembaga yang terkemuka dalam proses pemerintah negara Indonesia dan menunjukan secara spontan kepada warga desa. agar sukses ataupun tidak sukses pencapaian lewat tujuan dilaksanakannya hak daerah/desa dalam suatu negara pemerintahan tergantung kepada setiap beberapa baiknya kualitas pemerintaha desa di dalam mengimplementasikan peranan, fungsi dan wewenang sebagai pelayan masyarakat desa terkemuka. Kawasan desa dalam menjalankan hak, kebebasan serta kewajibannya dalam mengatur kemampuan dan keahlian yang diperoleh diarahkan untuk dijalankan dengan keterbukaan dan mempunyai tanggungjawab yang tinggi dan terdepan. Sesuai disusunya APBDes tentu dengan adanya Dana Desa menjadikan suatu desentralisasi yang dapat mendorong terciptanya good governance ialah terselenggaranya pemerintahan dalam perencanaan pembangunan yang baik dan bertanggung jawab tentu sesuai dengan prinsip kesatuan yang berlaku dan nilai pasar yang bernilai tinggi, selain itu kehindaran salah satu keuangan investasi dan dana mencegahnya pencucian dana baik secara tertutup maupun terbuka, menjalankan disiplin anggaran serta menciptakannya sifat yang teratur dan kerja politik bagi setiap pertumbuhan aktivitas usaha perekonomian indonesia (Mardiasmo,2013:18). Menurut Peraturan Pemerintah No. 60 Tahun 2014 suatu keuangan Desa yang berasal dari Anggaran Pendapatan dan Belanja Negara adalah keuangan yang diberikan kepada pemerintah kabupaten/kota untuk setiap desa secara khusus di indonesia, yang berasal dari bagian dana perimbangan keuangan pusat dan daerah yang diperoleh oleh seluruh kabupaten/kota. Permasalahan yang ditemui peneliti pada saat observasi awal yaitu dalam pengelolaan Alokasi Dana Desa untuk Transparasinya masih belum dijalankan dengan baik dimana tidak ada informasi di papan pengumuman atau papan informasi mengenai jumlah pengeluaran maupun pemasukan dalam menjalankan kegiatan Alokasi Dana Desa. Selain itu dalam akuntabilitas permasalahan yang ada, dimana masih rendahnya kapasitas aparatur pemerintah desa, dalam penguasaan teknologi, manajemen, dan pelayanan kepada masyarakat. Maka melalui skripsi ini penulis membahas mengenai transparansi dan akuntabilitas otonomi desa yang berfokus pada pengelolaan dan pertanggungjawaban Alokasi Dana Desa.

\section{TINJAUAN PUSTAKA}

Akuntansi. Akuntansi ialah cabang atau kriteria mencatat, menggolongkan, dan meringkas seluruh data keuangan yang konsumtif dan terukur agar membentuk mata uang, bagi setiap transaksi-transaksi atau kejadian-kejadian dari dana-dana suatu kantor perolehannya. (Tanor, 2015).

Akuntansi Sektor Publik. Akuntansi sektor publik ialah kriteria mencatat, mengklasifikasikan, menganalisis dan melaporkannya suatu bagian keuangan dari suatu kumpulan bagian publik yang memberikan informasi dana kepada para pengguna laporan keuangan yang digunakan untuk mengambil keputusan (Norwadian,2013).

Akuntansi Pemerintah. Akuntansi pemerintahan ialah berbagai aktivitas yang memberikan jasa keuangan untuk penyediaan informasi keuangan pemerintah dalam hal proses mencatatan, mengklasifikasian, mengikhtisaran suatu transaksi keuangan pemerintah negara serta penafsiran atas informasi keuangan perusahaan (Bachtiar dkk, 2014:3).

Dana Desa. Berdasarkan Peraturan Pemerintah No.60 tahun 2014 mengenai Dana Desa yang berasal dari keuangan Pendapatan dan Belanja Daerah ialah biaya yang disalurkan ke setiap pemerintah kabupaten/kota untuk setiap desa, yang bersumber berasal Anggaran 
Pendapatan dan Belanja Negara bagian dari keuangan perimbangan keuangan pusat dan daerah yang diperoleh oleh kabupaten/kota.

Penggangaran Dana Desa. Penggangaran Dana Desa sesuai dalam dalam peraturan pemerintah adalah suatu tatanan atau bagian dari keuangan Belanja Pusat nonkementerian/lembaga sebagai suatu kotak cadangan keuangan Desa. Proses menyusun pagu keuangan cadangan Dana Desa dijalankan sesuai kepada ketentuan yang berlaku sesuai peraturan undang-undangan di bagian bidang keuangan disusunya rencana keuangan pengeluaran/penerimaan Bendahara Umum Negara.

\section{Pengalokasian Dana Desa}

1. Tahap dialokasikan Dana Desa ke Setiap kabupaten/Kota di Indonesia.

2. Tahap dialokasikan Dana Desa ke setiap Desa Provinsi.

\section{Penyaluran Dana Desa}

1. Penyaluran Tahap 1 pada April sebesar $40 \%$

2. Penyaluran Tahap 2 pada Agustus sebesar $40 \%$

3. Penyaluran Tahap 3 pada November sebesar $20 \%$.

Penggunaan Dana Desa. Proses penggunaan Dana Desa dipakai untuk menganggarkan setiap terjadinya suatu terselenggaranya pemerintahan desa, pembangunan desa, diberdayakan masyarakat desa, dan kemasyarakatan desa.

Pelaporan Dana Desa. Proses disampaikannya laporan realisasi anggaran penggunaan dana desa ke setiap kabupaten/kota sebagaimana berlaku dalam ketentuan : (1) tahap Semester I minggu ke-4 juli menurut tahun anggaran berjalan; dan (2) tahap Semester II minggu ke-4 januari menurut tahun anggaran berikutnya.

Pemantauan dan Evaluasi Dana Desa. Proses Pemantauan dan evaluasi dilaksanakan kepada setiap Menteri Direktur Jendral perimbangan keuangan perusahaan diikutuoleh setiap para pejabat dalam negeri dan desa,mencakup proses kemajuan daerah tertinggal dan miskin, dan perpindahan dari kota ke desa dengan menjalankan pemantauan dari pengalokasian, penyaluran, dan penggunaan keuangan desa.

Transparansi (Tranparancy). Transparansi merupakan suatu tolak ukur disusun prinsip keterbukaan yang tentu dapat menjadikan masyarakat terlebih khusus masyarakat desa untuk memperoleh dan mengetahui penjabarab akses informasi seluas-luasnya mengenai keuangan daerah/desa. (Mahmudi,2015 : 17-18).

Akuntabilitas (Accountibility). Akuntabilitas (Accountibility) adalah peran kewajiban/tanggungjawab yang dapat memperoleh tanggung jawab atau menjawab setiap keperluan dana, tentu menjelaskan suatu kinerja perusahaan dalam memperoleh tindakan seseorang badan hukum perusahaan dan mencakup kumpulan organisasi dari setiap pihak yang bersangkutan mempunyai hak dan wewenang dalam memperoleh suatu hasil dan tanggung jawab.

Otonomi Desa/Daerah. Otonomi Desa/Daerah adalah sebagai suatu otonomi asli, bulat, dan utuh tentu bukan merupakan suatu pemberian dari masyarakat pusat.

Penelitian Terdahulu. Beberapa penelitian sebelumnya yang pembuat jadikan sebagai suatu bagian penentuan dalam menjalankan penelitian pada Kantor Desa Kauneran Satu Kecamatan Sonder Kabupaten Minahasa, penelitian yang dilakukan oleh, Pada penelitian yang dilakukan Putra (2017) terkait Analisis tanggungjawab dan keterbukaan dikelolanya Alokasi Dana Desa menunjukkan bahwa pengelolaan Alokasi Dana Desa berjalan secara bertahap sudah menerapkan prinsip akuntabilitas yang didukung prinsip transparansi, partisipasi, dan reponsif. Pada penelitian yang dilakukan Darmiasih (2015) terkait Analisis Mekanisme penyaluran Alokasi Dana Desa pada pemerintah desa menunjukan bahwa mekanisme penyaluran ADD dalam APBDesa dilakukan berjalur yaitu : 1,2 dan 3. 


\section{METODE PENELITIAN}

Jenis Penelitian. Jenis penelitian ini merupakan suatu penelitian kualitatif dengan pendekatan analisis deskriptif.

Tempat dan Waktu Penelitian. Penelitian ini dilakukan di Desa Kauneran Satu, Kecamatan Sonder, Kabupaten Minahasa. Penelitian ini dimulai pada bulan Mei sampai dengan bulan Juni 2018.

\section{Jenis, Sumber, dan Metode Pengumpulan Data.}

1. Jenis Data. Suatu Jenis penelitian yang dipakai ialah data kualitatif yang diperoleh dari hasil wawancara Kepala Desa Kauneran Satu Kecamatan Sonder Kabupaten Minahasa.

2. Sumber Data. Sumber Data dari penelitian ini didapat dari Data primer. sumber data penelitian ini yang tentu secara langsung memperoleh data kepada pengumpul data skripsi.

3. Metode Pengumpulan Data. Agar mendapatkan data yang diperoleh dalam penelitian ini, maka metode pengumpulan data yang dipakai yaitu : (1) observasi; dan (2) wawancara.

Metode Analisis. Metode penelitian ini menggunakan metode Analisis Deskriptif. Dalam hal ini dokumen yang perlu dianalisis dari dikumpulkannya data-data yang berhubungan kepada Dana Desa, antara lain:

1. Menghitung Mekanisme Anggaran Penyaluran Alokasi Dana Desa di Desa Kauneran 1 Kecamatan Sonder Tahun 2016-2018.

2. Menghitung Pengalokasian dari Pengelolaan Dana Desa di Desa Kauneran 1 Kecamatan Sonder Tahun 2016-2018.

\section{HASIL PENELITIAN DAN PEMBAHASAN}

\subsection{Hasil Penelitian}

Menghitung Mekanisme Anggaran Penyaluran Dana Desa pada Desa Kauneran

Satu Kecamatan Sonder Kabupaten Minahasa. Proses penyaluran keuangan dana Desa sebagaimana dimaksud dalam PP No.60 Tahun 2014 ayat 1 dilakukan dengan cara pemindahbukuan dari RKUN (Rekening Kas Umum Negara) ke RKUD (Rekening Kas Umum Desa) desa kauneran satu.Proses Penyaluran keuangan Dana Desa dijalankan secara berjalur pada setiap tahun keuangan berjalan sesuai ketentuan :

1. Penyaluran Tahap 1 pada Mei sebanyak $40 \%$.

2. Penyaluran Tahap 2 pada Juli sebanyak $40 \%$.

3. Penyaluran Tahap 3 pada November sebanyak $20 \%$.

Menurut penuturan Kepala Desa Kauneran Satu yaitu Bpk.Frangky Keintjem berdasarkan hasil wawancara mengenai penyaluran Alokasi Dana Desa (ADD) dari pemerintah ke Desa adalah sebagai berikut :"Penyaluran Dana Desa dari pemerintah ke Desa pertama melalui banyak tahapan yaitu Laporan LPJ,mengajukan proposal dan pengajuan dana di bidang keuangan aset daerah setelah ada persetujuan dari bupati untuk pencairan dana, tanda tangan sepsimen dari Hukum Tua, Sekdes baru bisa dilakukan pencairan dana. Ada tiga tahap pencairan yaitu : Tahap 40\%, Tahap 40\%, dan Tahap 20\%, Dana desa dicairkan sebesar 1 Miliar/tahun pencairan dana dilakukan secara Triwulan." (Hasil wawancara dengan Kepala Desa, Pada 22 Mei 2018). Adapun tahap-tahap dalam mekanisme penyaluran dan pencairan dana Alokasi Dana Desa :

1. Masyarakat Desa menampilkan rekening dari Bank yang ditunjukkan sesuai ketetapan pemerintah Desa Kauneran.

2. Pemerintah Desa memberikan permohonan penyaluran Dana Desa (DD) beserta kelengkapan lampiran kepada setiap Bupati dan pejabat pengelolaan keuangan daerah/Bendahara Umum daerah lewat Camat setelah dijalankan diperiksa oleh kelompok pendamping kecamatan. 
3. Pejabat Pengelolaan Keuangan Daerah/Bendaharawan umum setiap daerah tentu menyalurkan Dana Desa langsung/transfer yang ditransfer ke rekening bank umum daerah ke rekening desa.

4. Proses disalurkannya pencairan Dana Desa (DD) dalam (APBDesa) dijalankan secara bertahap yaitu 1,2, dan 3 yang dilengkapi dengan surat balasan dari camat menyertakan surat pertanggungjawaban tahun sebelumnya telah dijelaskan oleh desa ke kecamatan dan memperoleh kajian kembali kecamatan.

5. Karena sesuatu hal tahap sebelumnya belum dapat dicairkan, maka pencairan akan diakumulasikan ke tahap berikutnya.

Proses mengelola keuangan dana desa tentu dijalankan secara barhasil guna dan bernilai guna, terbuka, dan bertanggungjawab. Swadaya masyarakat ialah bukti bantuan di Desa Kauneran Satu Kecamatan Sonder yaitu :

Tabel 1. Penyaluran Alokasi Dana Desa dan Swadaya Masyarakat di Desa Kauneran Satu Kecamatan Sonder Tahap 1 Tahun 2016-2018

\begin{tabular}{|c|c|c|c|c|}
\hline No & Tahun & Jumlah ADD & Swadaya Masyarakat & \% \\
\hline 1 & 2016 & 290.340 .000 & 5.000 .000 & - \\
\hline 2 & 2017 & 297.561 .000 & 5.000 .000 & - \\
\hline 3 & 2018 & 293.082 .000 & 5.500 .000 & 12,38 \\
\hline
\end{tabular}

Sumber : Laporan Alokasi Dana Desa di Desa Kauneran Satu Kecamatan Sonder, 2018

Dari tabel 1 diatas menunjukan hasil dari penyaluran ADD dan swadaya masyarakat desa dengan memperhatikan proses pertanggung jawaban Alokasi Dana Desa yang sudah berjalan dengan baik dikarenakan dalam pengambilan dana sebesar $100 \%$, sesuai pengeluaran keuangan desa Kauneran satu kecamatan Sonder Kabupaten Minahasa.

Tabel 2. Data Alokasi Dana Desa Kauneran Satu Kecamatan Sonder Kabupaten Minahasa Pada Akhir Tahun 2018

\begin{tabular}{|c|c|c|c|c|}
\hline No & Nama Desa & ADD & \multicolumn{2}{|c|}{ Hasil Tanggung Jawab } \\
\cline { 4 - 5 } & & & Fisik & Dana \\
\hline 1 & Kauneran Satu & 293.082 .000 & $100 \%$ & Lengkap \\
\hline
\end{tabular}

Sumber : Data SPJ (Surat Pertanggungjawaban) ADD Desa Kauneran Satu Kecamatan Sonder.

Dari tabel 2 diatas menghasilkan tanggungjawaban ADD telah lengkap jadi tidak tentu harus dijalankan lewat pembelajaran dalam menunjang menuju tertib administrasi ADD. Hasil pembangunan desa dapat diperoleh dengan pencapaian hasil yang berupa pembangunan fisik/infrastruktur di Desa Kauneran Kecamatan Sonder Sesuai Tabel berikut ini : 
Tabel 3. Daftar Sarana Prasarana di Desa Kauneran Satu Kecamatan Sonder Kabupaten Minahasa yang didirikan Dari ADD Tahun 2018

\begin{tabular}{|c|c|c|c|}
\hline No & Nama Desa & Sarana yang Didirikan & Hasil \\
\hline \multirow{4}{*}{1} & Kauneran Satu & Betonisasi Bahu Jalan & Baik \\
\cline { 3 - 4 } & & Perbaikan Jalan & Baik \\
\cline { 3 - 4 } & Pemasangan Pafing & Baik \\
\cline { 3 - 4 } & Talud Pasangan Batu Tipe 1 & Baik \\
\cline { 3 - 4 } & Talud Pasangan Batu Tipe 2 & Baik \\
\cline { 3 - 4 } & Penerangan Lampu Tenaga Surya & Baik \\
\cline { 3 - 4 } & Saluran Drainase & Baik \\
\cline { 3 - 4 } & & Pemeliharaan Lampu Jalan & Baik \\
\hline
\end{tabular}

Sumber : Laporan Akhir Alokasi Dana Desa di Desa Kauneran Satu Kecamatan Sonder Kabupaten Minahasa Tahun 2018 dan Hasil Observasi Lapangan.

Dari tabel 3 tersebut menunjukan bahwa pembangunan sarana prasarana di Desa Kauneran Satu telah berjalan dengan Baik.

\section{Menghitung Pengalokasian dalam Pengelolaan Dana Desa pada Desa Kauneran Satu Kecamatan Sonder Kabupaten Minahasa.}

1. Total Penduduk Desa Kauneran Satu.

Total penduduk desa kauneran satu pada tahun 2018 sebanyak 1.483 Jiwa, dimana wanita sebanyak 890 Jiwa dan Pria 697 Jiwa dengan 516 KK. Jumlah penduduk desa, luas wilayah desa, dan jumlah kemiskinan sebagaimana dimaksud pada ayat 2 PP No.60 Tahun 2014 dibuat sesuai ketentuan : (a) 30\% jumlah penduduk desa; (b) 20\% luas wilayah; dan (c) $50 \%$ angka kemiskinan desa.

2. Tingkat Kesulitan Geografis Desa Kauneran Satu.

Tingkat kesulitan geografis desa kauneran satu digunakan dari faktor memperoleh hasil perhitungan sebagaimana dimaksud pada diatas. Kesulitan geografis di desa kauneran cukup diperhitungakan dalam mengalokasikan dana desa dari pemerintah pusat ke daerah/desa.

Besaran Dana Desa setiap desa terlebih khusus desa kauneran satu dihitung lewat cara :

1. Dijelaskan bahwa Dana Desa untuk suatu desa $=$ Pagu Dana Desa kabupaten $/$ kota $\times(30 \%$ $\times$ presentase jumlah penduduk desa yang bersangkutan terhadap total desa di kabupaten /kota yang bersangkutan $)+(20 \% \times$ presentase luas wilayah desa yang bersangkutan terhadap total luas wilayah desa di kabupaten/kota yang bersangkutan $+(50 \% \times$ presentase rumah tangga pemegang kartu perlindungan sosial terhadap total jumlah rumah tangga desa di kabupaten/kota yang bersangkutan); dan

2. Dijelaskan hasil perhitungan dana desa sesuai yang dijelaskan pada nomor 1 disesuaikan dengan tingkat kesulitan geografis di desa Kauneran Satu. 
Tabel 4. Laporan Pendapatan Desa Kauneran Satu Tahun Anggaran 2018

\begin{tabular}{|c|c|c|c|}
\hline $\begin{array}{c}\text { KODE } \\
\text { REK }\end{array}$ & URAIAN & $\begin{array}{c}\text { ANGGARAN } \\
\text { (Rp) }\end{array}$ & KETERANGAN \\
\hline 1 & 2 & 3 & 4 \\
\hline 1. & PENDAPATAN & & \\
\hline 1.1 & Pendapatan Asli Daerah & $5.500 .000,00$ & \\
\hline 1.1 .3 & Swadaya \& Gotong royong & $5.500 .000,00$ & \\
\hline 1.2 & Pendapatan Transfer & 953.758.000,00 & \\
\hline 1.2 .1 & Dana Desa & $636.401 .000,00$ & \\
\hline 1.2 .2 & Hasil Pajak \& Retribusi & $24.275 .000,00$ & \\
\hline \multirow[t]{2}{*}{1.2 .3} & Alokasi Dana Desa & $293.082 .000,00$ & Tahap I \\
\hline & JUMLAH PENDAPATAN & 959.258.000,00 & \\
\hline
\end{tabular}

Sumber : Laporan Alokasi Dana Desa Kauneran Satu Kecamatan Sonder, 2018

Dari tabel 4 dijelaskan bahwa Alokasi Dana Desa diperoleh dari Pendapatan Asli Daerah lewat transfer Dana Desa tahap I sebesar Rp.636.401.000 dengan presentase 40\% pada bulan april ke Pemerintah Desa, Pendapatan asli daerah dan pendapatan transfer memiliki hasil yang berbeda dalam mengelola Dana Desa pada Desa Kauneran Satu Kecamatan Sonder Kabupaten Minahasa. Hasil tersebut bahwa Pemerintah Desa Kauneran Satu memberikan Transparansi dan Akuntabilitas yang baik bagi masyarakat Desa Kauneran Satu dalam menggunakan dana desa sesuai kebutuhan desa yang bersangkutan guna menciptakan desa yang tentram.

Tabel 5. ADD Tahun 2018 pada Desa Kauneran Satu Kecamatan Sonder

\begin{tabular}{|c|c|c|c|c|}
\hline $\begin{array}{c}\text { No } \\
\text { Rek }\end{array}$ & Desa & Uraian & $\begin{array}{c}\text { Besarnya } \\
(\mathbf{R p})\end{array}$ & $\begin{array}{c}\text { Keteranga } \\
\mathbf{n}\end{array}$ \\
\hline $\mathbf{1}$ & $\mathbf{2}$ & $\mathbf{3}$ & $\mathbf{4}$ & $\mathbf{5}$ \\
\hline & Kauneran & Penyelenggaraan Pemerintah & & \\
2.1 & Satu & Desa & 220.232 .000 & \\
\hline 2.2 & & Pelaksanaan Pembangunan Desa & 471.313 .800 & \\
\hline 2.3 & & Pembinaan Kemasyarakatan & 39.875 .000 & \\
\hline 2.4 & & Pemberdayaan Masyarakat & 82.837 .200 & \\
\hline & & Jumlah & $\mathbf{8 1 4 . 2 5 8 . 0 0 0}$ & \\
\hline & & Surplus/Defisit & 145.000 .000 & \\
\hline
\end{tabular}

Sumber : Laporan Perencanaan Alokasi Dana Desa pada Desa Kauneran Kecamatan Sonder Kabupaten Minahasa, 2018

Dari tabel 5 diatas dijelaskan bahwa hasil perencanaan tersebut akan menjadi pedoman penyelenggaraan pemerintahan desa, Pelaksanaan Pembagunan Desa, Pembinaan Kemasyarakatan dan Pemberdayaan Masyarakat dengan kurun waktu satu tahun. Dari hasil tersebut membuktikan bahwa transparansi dan akuntabilitas pada desa Kauneran Satu menjadi salah satu tolak ukur pemerintah desa untuk mengelola Dana Desa dengan bijaksana.

\subsection{Pembahasan}

Analisis Mekanisme Anggaran Penyaluran Dana Desa pada Desa Kauneran Satu Kecamatan Sonder Kabupaten Minahasa. Proses disalurkannya keuangan desa dari Rencana Kerja Umum Daerah ke setiap rekening bank desa kauneran satu dijalankan sesuai APBDes dilakukan dan diterapkan. penetuan lanjut menjelaskan pemakaian penyaluran keuangan dana desa sesuai dalam aturan menteri dalam nergeri. Lewat Penggunaan keuangan Dana Desa dipakai untuk membayar terselenggarannya pemerintahan desa, 
pembangunan desa, pemberdayaan masyarakat desa, dan kemasyarakatan pada Desa Kauneran Satu Kecamatan Sonder. Dana desa diutamakan dengan membiayai pembagunan dan pemberdayaan masyarakat desa.

Analisis Pengalokasian dalam Pengelolaan Dana Desa pada Desa Kauneran Satu Kecamatan Sonder Kabupaten Minahasa. Pengalokasian dana lewat Pemerintah pusat indonesia menerapkan besaran keuangan Dana Desa bagi setiap Desa di setiap provinsi secara khusus desa kauneran satu. Besar dana desa yang telah dihitung berdasarkan jumlah penduduk desa, luas wilayah desa, angka kemiskinan desa dan tingkat kesulitan geografis. Dana desa secara khusus untuk membiayai pembagunan dan pemberdayaan masyarakat desa.

\section{KESIMPULAN DAN SARAN}

\subsection{Kesimpulan}

Melalui hasil diatas dan pembahasan yang telah disalurkan sebelumnya jadi diangkat diambil kesimpulan yang dapat menjawab permasalahan dalam penelitian ini adalah disalurkannya Alokasi Dana Desa (ADD). Bagi hasil pajak, dan Bagi hasil Retribusi dijelaskan mekanisme penyaluran pengelolaan pengalokasian ADD lewat Anggaran Pendapatan Belanja Desa (APBDesa) dijalankan secara bertahap dengan melalui 3 tahap penyaluran dana desa.

\subsection{Saran}

Berdasarkan hasil penelitian dan analisis yang telah dilakukan sebelumnya, maka penulis memberiskan saran antara lain :

1. Pemerintah Desa sudah melakukan dan menjalankan faktor transparansi dengan memasang baliho anggaran Alokasi Dana Desa di papan informasi kantor Desa Kauneran satu dan saran peneliti agar disetiap Dusun/jaga di pasang juga baliho anggaran ADD sehinggan mampu meningkatkan dukungan dan kepercayaan masyarakat terhadap aparatur desa.

2. Tetap mempertahankan faktor-faktor akuntabilitas dan transparansi dalam mengelola Dana Desa (DD) di Desa Kauneran Satu, Kecamatan Sonder, Kabupaten Minahasa yang sudah dijalankan, sehingga dapat melakukan tugas maupun tanggungjawab dengan baik.

\section{DAFTAR PUSTAKA}

Atmaja, dkk.2013. Definisi Entitas Accountabel yang mampu menyediakan informasi secara terbuka mengenai keputusan yang diambil. Jakarta.

Bastian, Indra.2015 Definisi Akuntansi Sektor Publik. Erlangga. Jakarta.

Bachtiar, Arif .2014.Definisi Akuntansi Pemerintahan. Erlangga. Jakarta.

Mahmudi.2015. Manajemen Keuangan.Jakarta. Airlangga.

Mardiasmo.2014.Menurut United Nation Development Program tentang Transparansi. Yogyakarta.

Mardiasmo.2014. Akuntabilitas dan Transparansi. Yogyakarta.

Mardiasmo.2013. Teori menjalankan disiplin anggaran serta penciptaan legal and political framework bagi tumbuhnya aktivitas usaha. Yogyakarta

Peraturan Pemerintah Nomor 60 Tahun 2014 tentang Dana Desa Bersumber dari Anggaran Pendapatan dan Belanja Daerah (APBN).

Putra, I. Putu, dkk.2017. Analisis.Akuntabilitas dan Transparansi Pengelolaan Alokasi Dana Desa di desa Bubunan. Jurnal Akuntansi Volume 8 No:2, Jurusan Akuntansi, Universitas Pendidikan Ganesha.

Setiawan.M.D,dkk.2017. Analisis Transparansi dan Akuntabilitas Pelaporan Alokasi Dana Desa. Jurnal Akuntansi Volume 7 No: 1, Jurusan Akuntansi, Universitas Pendidikan Ganesha.Singaraja.

Riyanto. 2015. Definisi Akuntansi Pemerintahan. Jakarta. 
Setiawan.M.D,.2017. Analisis Transparansi dan Akuntabilitas Pelaporan Alokasi Dana Desa. Jurnal Akuntansi Volume 7 No:1, Jurusan Akuntansi, Universitas Pendidikan Ganesha.Singaraja.

Solekhan,M.2013. Penyelenggaraan Pemerintah Desa Berbasis Partisipasi Masyarakat dalam Membangun Mekanisme Akuntabilitas. Malang: Setara press. 